\title{
ロッキング現象における一つの吟味
}

正員畑 野

\section{AN EXAMINATION OF THE ROCKING PHENOMENON}

\author{
By Dr. Eng., Tadashi Hatano C.E. Member
}

Synopsis : The reduction of velocity in the free rocking motion of a rigid body on a rigid base has been hitherto explained on the basis of constant angular momentum. According to this theory, an abrupt reduction of velocity, in other words energy of motion, is justifiable, when the rigid body falls down on the base, even in the ideal case neglecting energy consumption.

This paper reports observations and considerations on the free rocking of the graphite prisms on various bases, and it has been clarified that the application of the law of constant angular momentum is not suitable and the reduction of energy must be explained by sliding, elasticity, sound or others.

\section{1. 緒言}

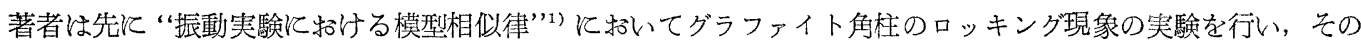
運動方程式によつて表わされる理想的ロッキング現象が実験的にかなりよく成立する事を示した。しかしこの際 ロッキングする物体の回転端が他端に移るとき，従来地震学者の間で採用されている理論が 再吟味を要するもの であることを指摘して执いた。ロッキング現象は墓石の転倒，その他によつて実際に起こつた地震の規模を論ず る上で相当重要な問題と考光られ，また基礎的な振動問題としても興味あることと思われるので，以下角柱の場 合を例にとつて, 簡単にこの問題に触れることにする。

\section{2. ロッキングの減衰に対する従来の取扱いとこれに対する批判}

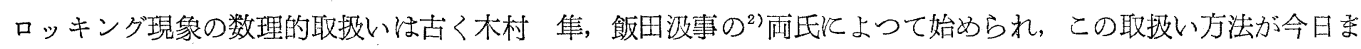
で是認されて各種の計算飞用いられている3゙。自由ロッキング括よび強制ロッキングの計算に捈いて，ロッキング する物体招よび地盤が剛体であつて，エネルギーの損失がないという理想的状態を想定して運動方程式を立て， これを解くと実験とかなりよく一致することはすでにのべだ”。いしロッキングの回転端が他端に移るときの条 件として, 最初の回転端のまわりの角運動量が回転を他端飞移寸前後に括いて等しいと括くと, 回転の前後飞招 けるロッキングの速度は不連続に減少し，その物体のエネルギーるまた急激に減少することになる。いまこれに 対する従来の理論を自由にロッキングついて書いてみる゙2。

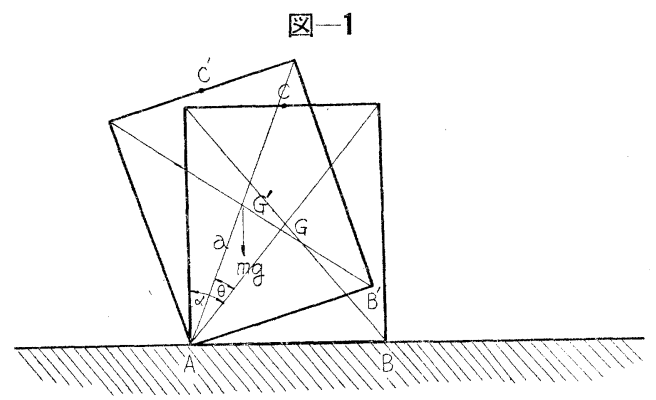

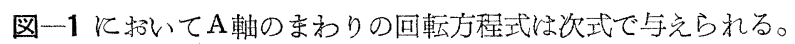

$$
\frac{d^{2} \theta}{d t^{2}}=\frac{-a g}{a^{2}+k^{2}} \sin (\alpha-\theta)
$$

$a:$ 重心よりA 軸炕下した垂線の長さ, $k:$ 重心のまわりの回転半径

任意の始角 $\theta_{0}$ より初速を与えないで落下させると，始めの位置のエネルギーが次第に運動のエネルギーとなり， B' 
点が $\mathrm{B}$ 点の位置にくるときは全部運動エネルギーに変化する。したがつてこのときの $\mathrm{A}$ 軸のまわりの角速度は次 式で与兄らる。

$$
\omega_{0}=\sqrt{\frac{2 a g\left\{\cos \left(\alpha-\theta_{0}\right)-\cos \alpha\right\}}{a^{2}+k^{2}}}
$$

次に回転軸が A から B そ移るとき，その前後飞抽ける角運動量飞変化がないといろ条件をとると， B軸を回転 軸とする回転の最初の角速度 $\omega_{0}^{\prime}$ は次式で与兄られる。

$$
\omega_{0}{ }^{\prime}=\frac{a^{2} \cos 2 \alpha+k^{2}}{a^{2}+k^{2}} \omega_{0}=(0.75 \cos 2 \alpha+0.25) \omega_{0}=\sigma \omega_{0}
$$

ここに。を変軸速度係数と呼び, 衝突のさいに拓ける速度は不連続に変化し, 音, 熱, 弾性, 等によるェネル ギー損失を一切考皇なくても, 角速度, 従つて運動エネルギーが減少することを示すととになる。次に初速 $\sigma \omega_{0}$ からBを軸として回転し, 重心 $G$ は始角 $\theta_{0}$ 上り上述運動エネルギーの減少分だけ小さな回転角まで上昇して, 再び下降し始め, A 軸が落下寸る直前は途中でエネルギー損失がないとしているから, 再び $\sigma \omega_{0}$ の速度となる。 落下直後は上述の理由で $\sigma^{2} \omega_{0}$ の角速度となつて以下ロッキングをくり返す。かくして角速度は等比級数的減少 乙自由ロッキングはとまるというのである。

以上の所論に括てエネルギーの消耗を全く考慮に入れないでいながら，結果的にエネルギーが減少してしま ろということは奇妙なことである。エネルギー消耗を考慮しなければ， ロッキングする物体作用する力は重力 という保存力のみであるから，エネルギー保存の法則が成立しなければならない。「外力の作用をうけないときに は，運動量柇存される」という運動量保存の法則を同一回転軸につき回転の前後飞適用するととには疑問があ る。

\section{3. 自由ロツキングの実験とその考察}

以上の疑問を明らか沉するため, $3 \mathrm{~cm}$ 角のグラファイト柱の高さ $12,9,6,3 \mathrm{~cm}$ の四者を自由ロッキングさせて その速度変化を記録してみた。十分堅固な実験台上飞木材の板，鉄のブロック，グラファイトのブロック招よび スポンジゴムの板を水平に固定し，この上飞角柱をたてて $12,9,6 \mathrm{~cm}$ の三種のものは図一-6,7,8 と示す $\mathrm{B}$ 点を軸 として回転し，C点がすべて静止の位置より水平に $2.0 \mathrm{~cm}$ だけ右方にあるようにして運動を始めた。 $3 \mathrm{~cm}$ 高さ のものだけは $2.6 \mathrm{~cm}$ の位置から運動を開始させた。記録は電磁オッシログラフを用い， C 点に軽いベークライト 製の台上淔径約 $0.1 \mathrm{~mm}$ のエナメル銅線を 30 回巻したコイルを固定し，このコイルが大型のマグネットの磁 界を切るようKした。オッシログラフに使用したガルバノメーターは固有振動数 $300 \mathrm{c} / \mathrm{s}$, 感度 $30 \mathrm{~mm} / \mathrm{mA}$ のも のでこれルェナメル銅線を直結して用いた。

この速度計を振動台を用いて検定した結果， $\pm 0.8 \%$ の誤差に括さまつた。図一2 5 はこの実験記録であつて この記録の再現性はきわめて確実である。な㧍, 回転軸を交換する前後の現象は不連続であるからガルバノメー ターの追随性を確める意味で, 直流増幅による陰極線オッシログラフの記録を追加した。

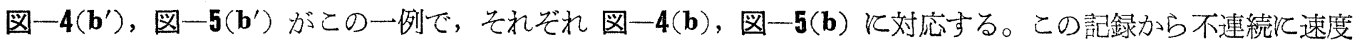
が変化する場合ガルバノメーターでは 1/200 sec ないし 1/100 sec 程度記録が遅くれる程度で, 汪とんど正確速 度の変化を記録し得ることがわかる。

自由ロッキングした場合の状沅を観察したるのを表一1 亿示す。な拉,グラファイト角柱と基礎飞用いた各材 料との間の静止の摩摖係数を実験して求めた值括よび角柱の形から定るま。值と後の議諭に必要な $3 / 8 \sin 2 \alpha の$ 值を付記して扮く。

これらの記録を用いてロッキングの回数に応じて速度が減少する状況を示したものは, 図一6,7,8,9である。こ の図の速度の值は A 端または B 端が落下したときのその点の速度の読みであつて，A 端が落下して $\mathrm{B}$ 端と移ると きのB端の速度ではない。すなわち不連続変化する場合の直前の值である。これらの図には第一回の落下速度を 基にして従来の理論による減衰の曲線をる付記した。これらの図招よび表からロッキングの速度減衰の原因が推 察される。すなわちロッキングする物体と基盤との間の摩擦, 弾性変形括よび角柱の形態が速度減衰牦重要な役 目をなし，更に運動途中の空気の抵抗，落下時飞発生する音，等がまた影響を与兄るるのであると推定される。

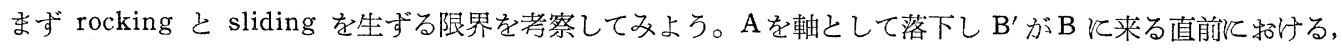
重心 G 亿作用する水平方向の慣性力は式 (1) を用いて次のよろとなる。

$$
\begin{gathered}
m a \frac{d^{2} \theta}{d t^{2}} \cos \alpha=-\frac{3}{4} m g \sin \alpha \cos \alpha \\
\text { ここに } m: \text { 角柱の質量 }
\end{gathered}
$$


图-2 (a) Free rocking of a graphite block $(12 \times 3 \times 3 \mathrm{~cm}$ prism) on a wooden plate.

(recorded with electro-magnetic oscillograph)

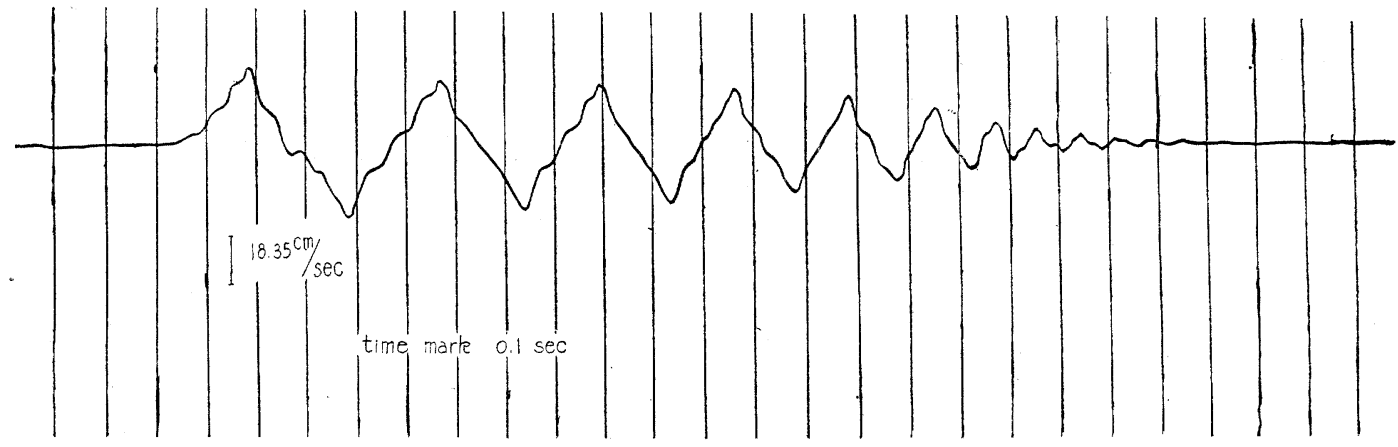

図-2 (b) Free rocking of a graphite block $(12 \times 3 \times 3 \mathrm{~cm}$ prism $)$ on a iron block.

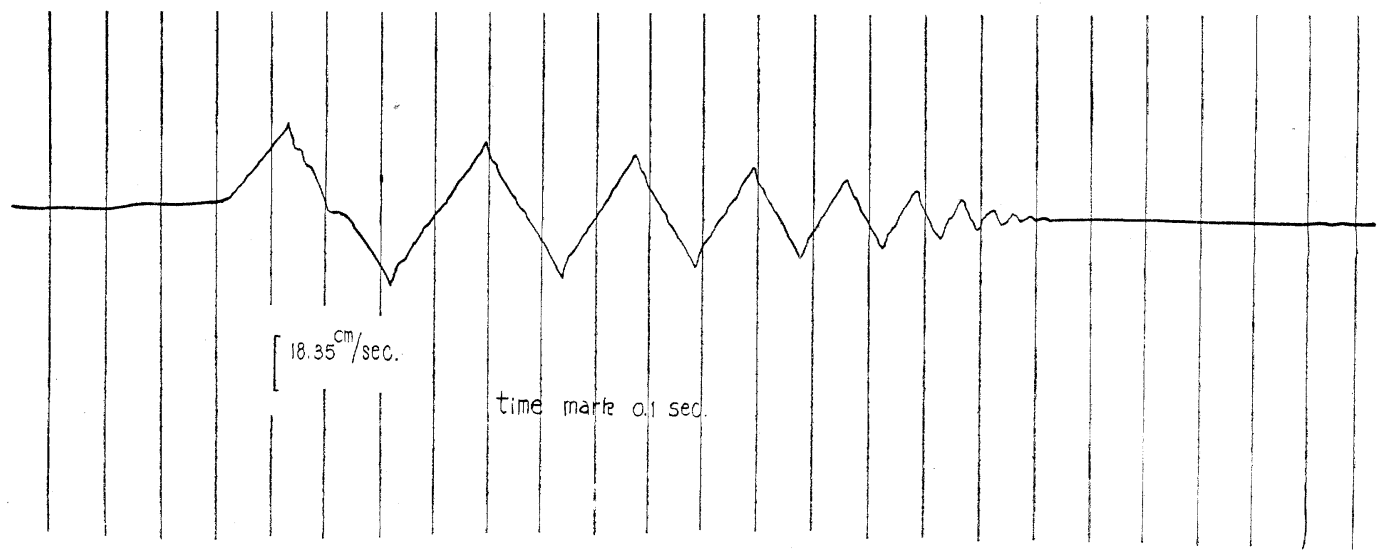

図-2 (c) Free rocking of a graphite block $(12 \times 3 \times 3 \mathrm{~cm}$ prism) on a graphite block.

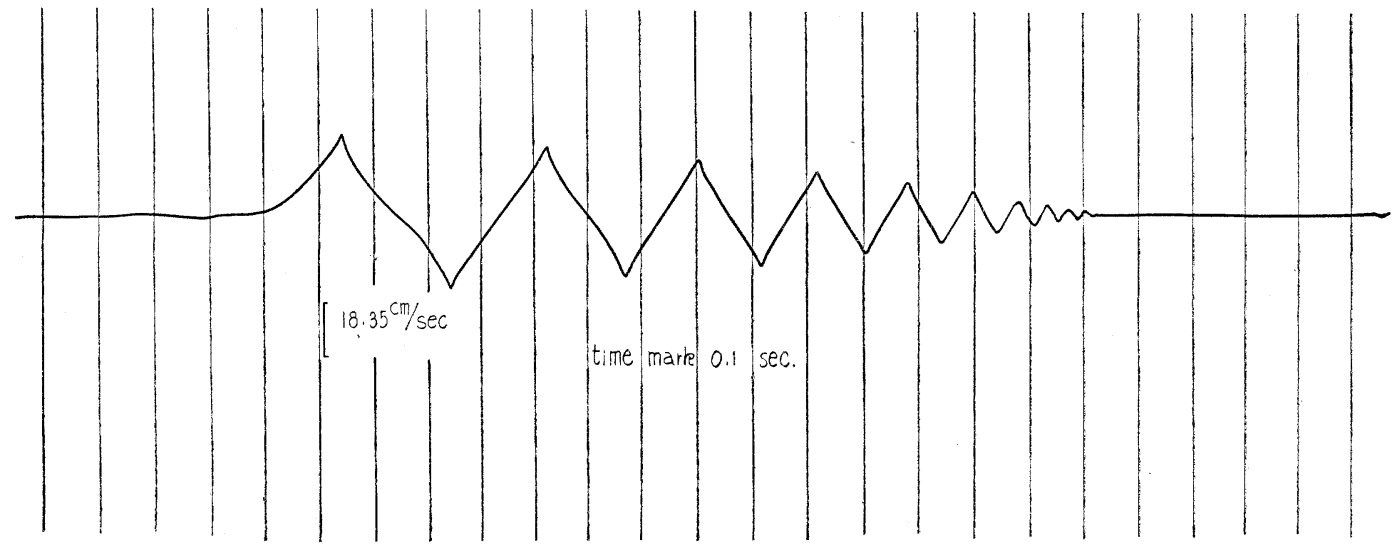


図-2 (d) Free rocking of a graphite block $(12 \times 3 \times 3 \mathrm{~cm}$ prism) on a sponge gum plate.

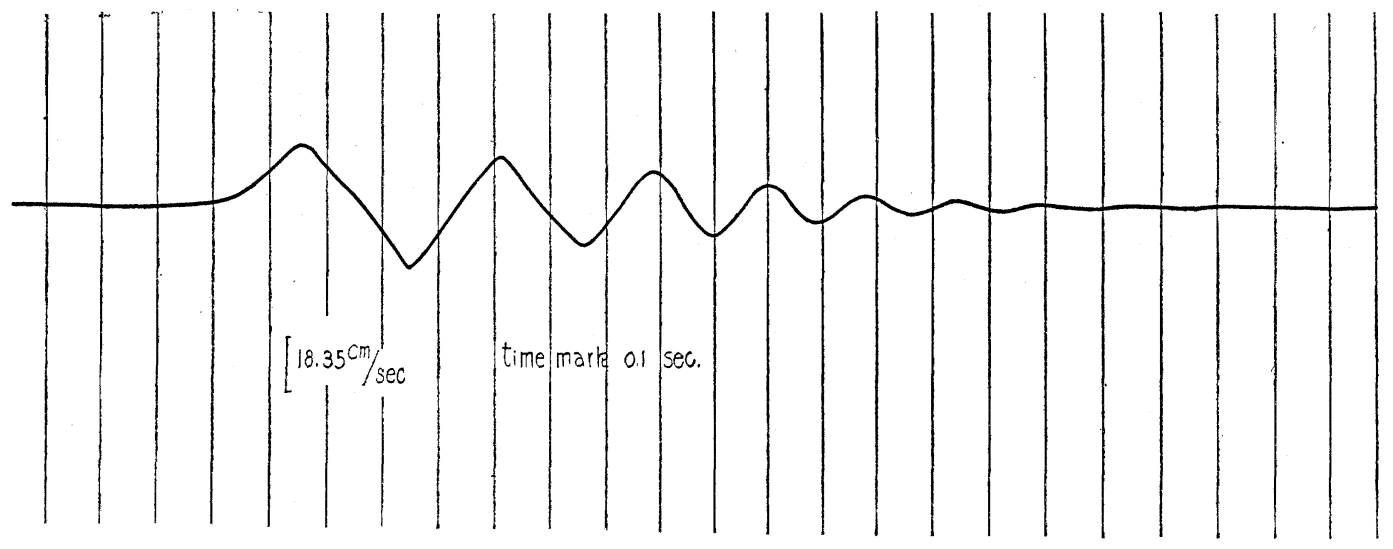

図-3 (a) Free rocking of a graphite block $(9 \times 3 \times 3 \mathrm{~cm}$ prism on a wooden plate.

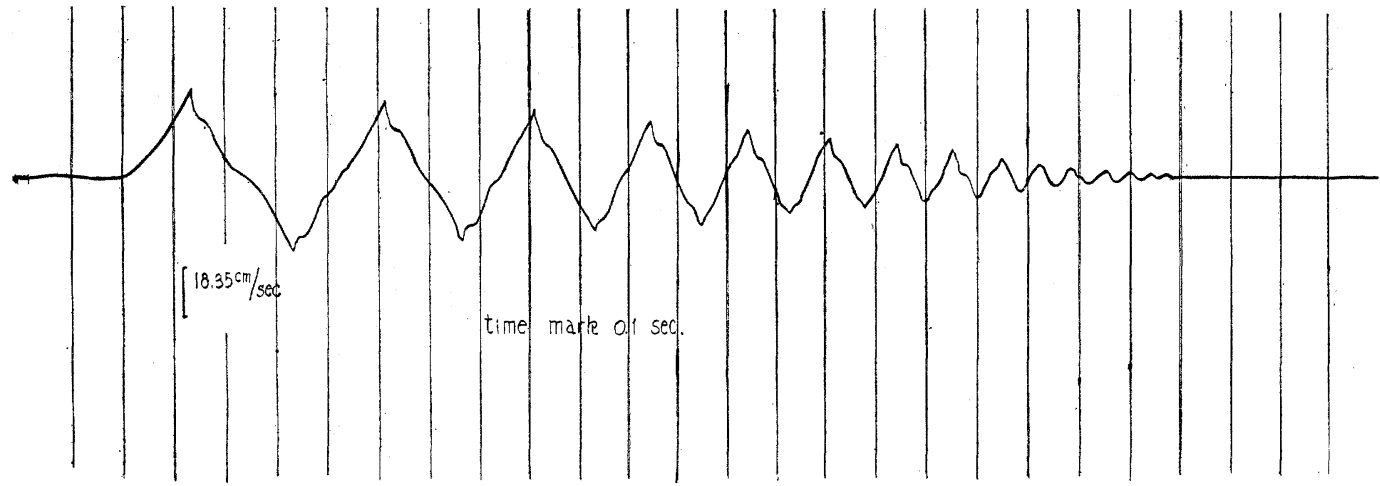

図-3 (b) Free rocking of a graphite block $(9 \times 3 \times 3 \mathrm{~cm}$ prism) on a iron block.

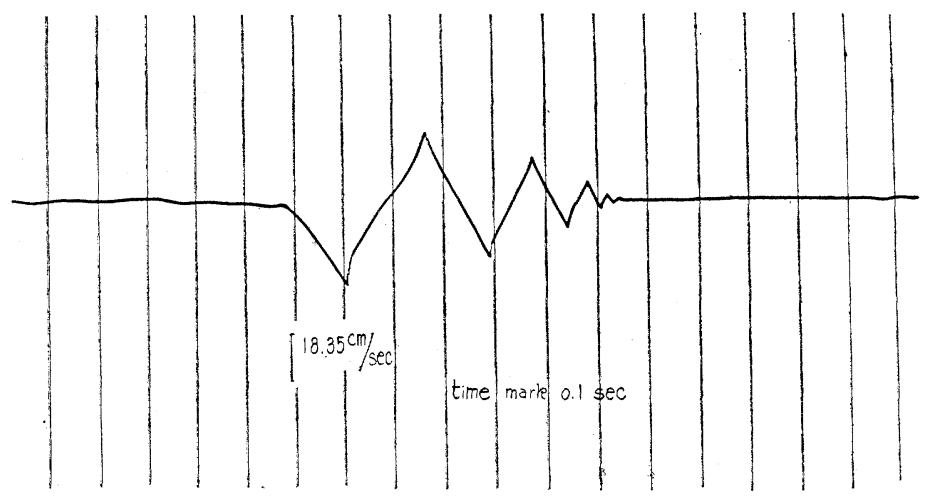


図-3 (c) Free rocking of a graphite block $(9 \times 3 \times 3 \mathrm{~cm}$ prism $)$ on a graphite block.

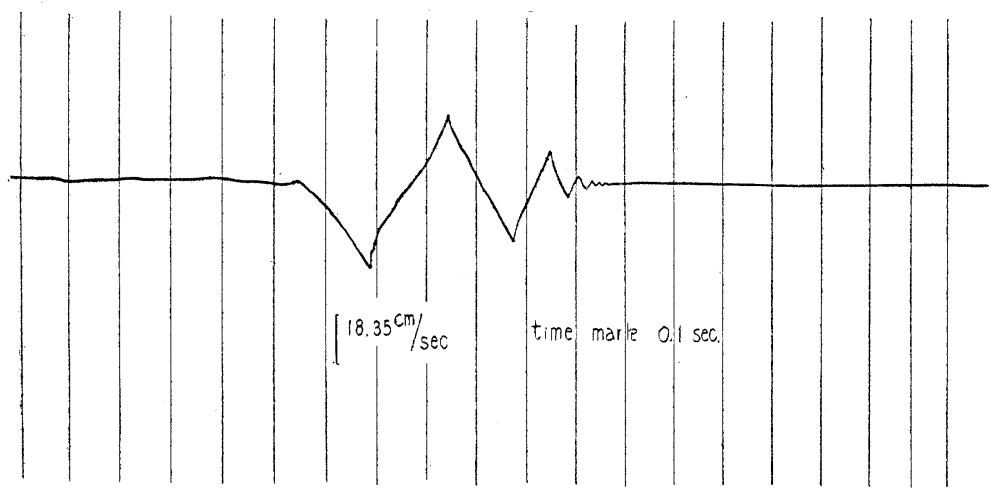

図-3 (d) Free rocking of a graphite block $(9 \times 3 \times 3 \mathrm{~cm}$ prism $)$ on a sponge gum plate.

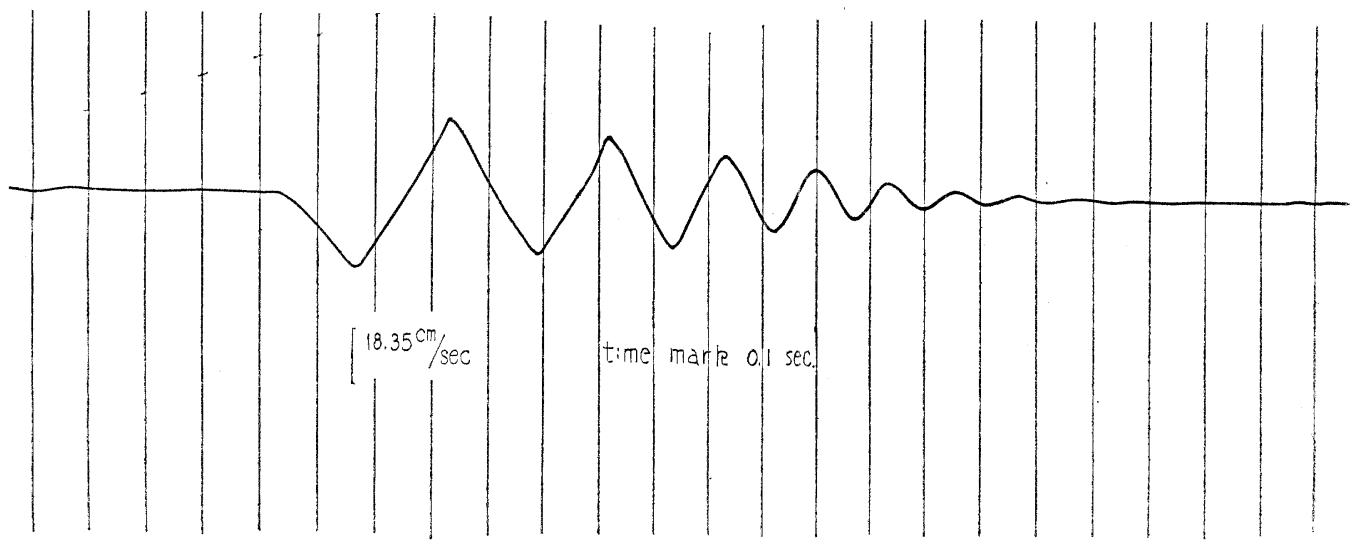

図-4 (a) Free rocking of a graphite block $(6 \times 3 \times 3 \mathrm{~cm}$ prism) on a wooden plate.

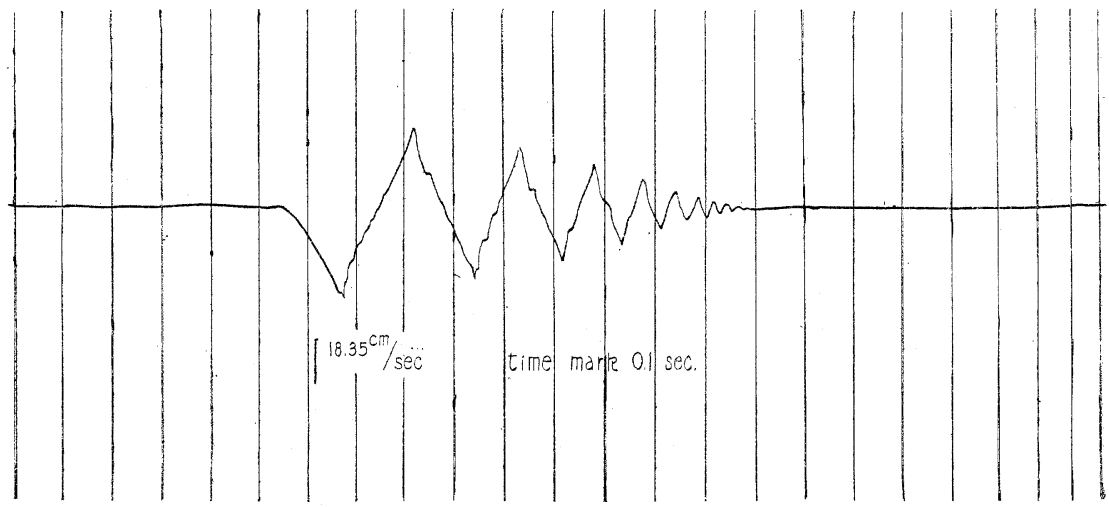


図-4 (b) Free rocking of a graphite block $(6 \times 3 \times 3 \mathrm{~cm}$ prism) on a iron block.

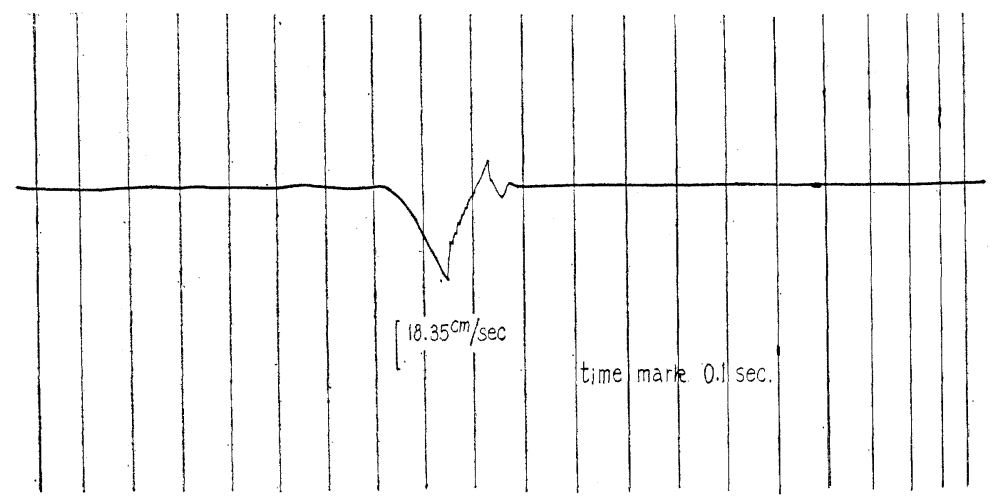

図-4(b') Free rocking of a graphite block $(6 \times 3 \times 3 \mathrm{~cm}$ prism) on a iron block.

(recorded with cathode ray oscilloscope)

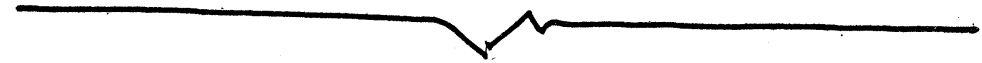

$0.1 \mathrm{sec}$

$1-1$

図-4 (c) Free rocking of a graphite block $(6 \times 3 \times 3 \mathrm{~cm}$ prism) on a graphite block.

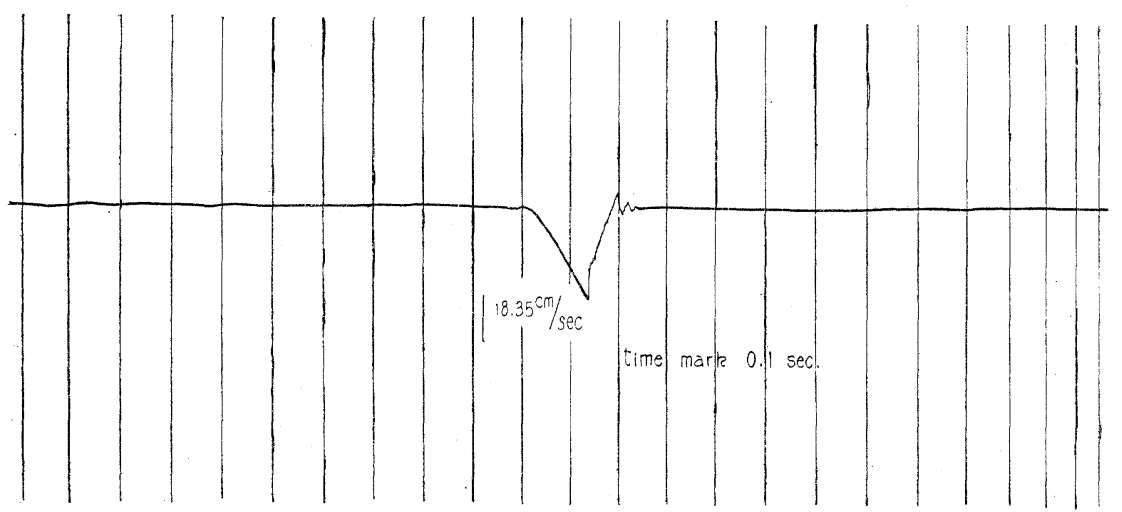


図-4(d) Free rocking of a graphite block $(6 \times 3 \times 3 \mathrm{~cm}$ prism $)$ on a sponge gum plate.

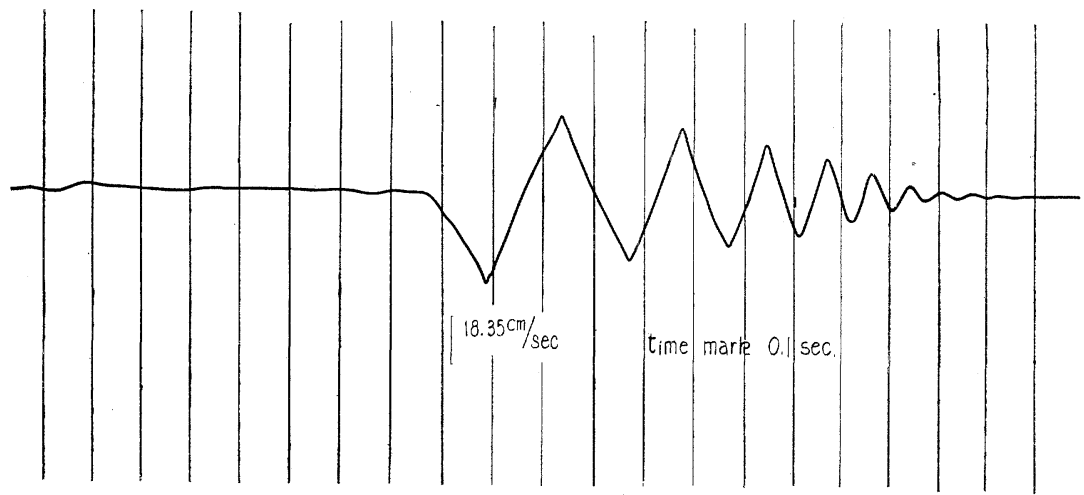

図-5 (a) Free rocking of a graphite block $(3 \times 3 \times 3 \mathrm{~cm}$ prism $)$ on a wooden plate.

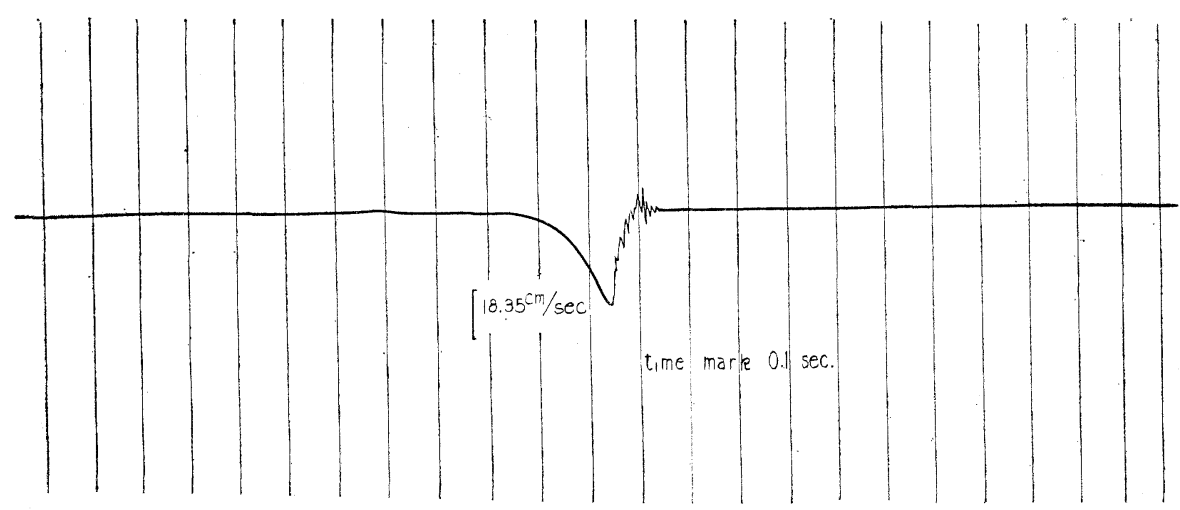

図-5 (b) Free rocking of a graphite block $(3 \times 3 \times 3 \mathrm{~cm}$ prism) on a iron block.

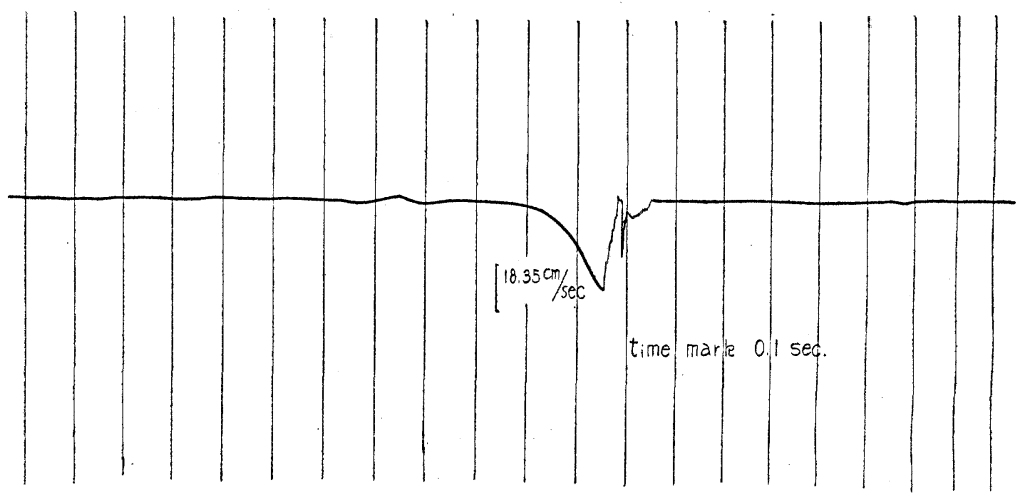




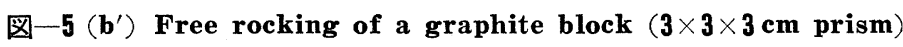
on a iron block.

(recorded with cathode ray oscilloscope)

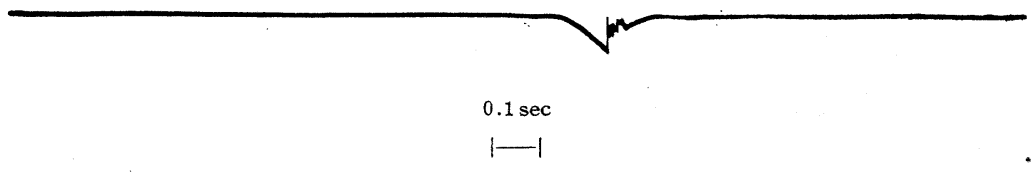

図-5 (c) Free rocking of a graphite block $(3 \times 3 \times 3 \mathrm{~cm}$ prism $)$ on a graphite block.

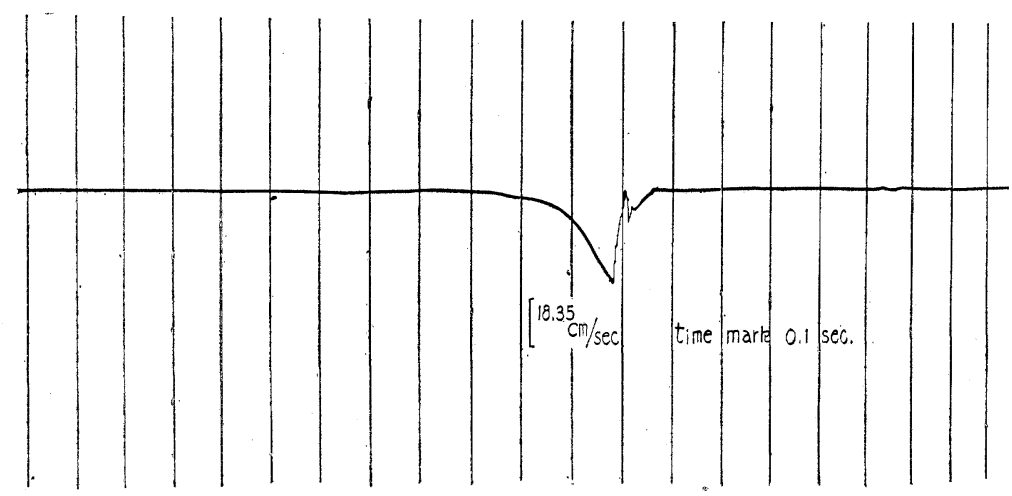

図-5 (d) Free rocking of a graphite block $(3 \times 3 \times 3 \mathrm{~cm}$ prism) on a sponge gum plate.

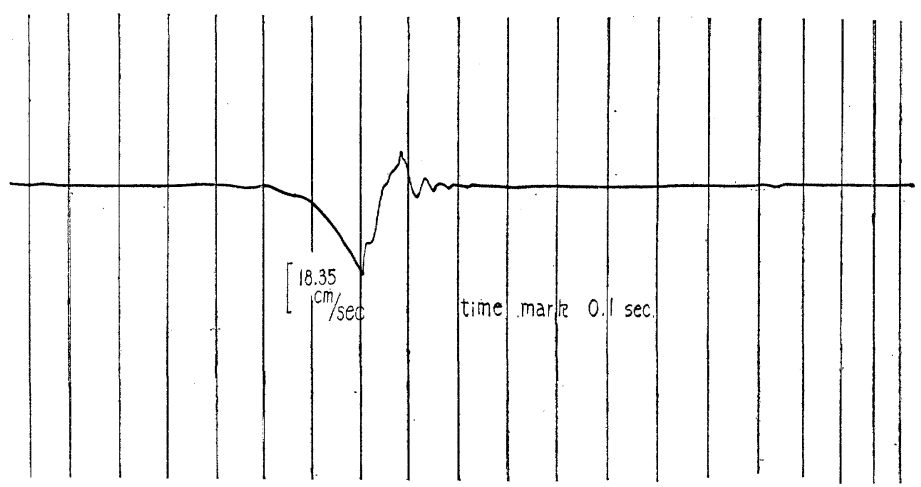

表-1 Observation on free rocking of a graphite prism

\begin{tabular}{l|c|c|c|c|c}
\hline & prism $12 \times 3 \mathrm{~cm}$ & prism $9 \times 3 \mathrm{~cm}$ & prism $6 \times 3 \mathrm{~cm}$ & prism $3 \times 3 \mathrm{~cm}$ & $\begin{array}{c}\text { coeff of friction } \\
\text { (static) }\end{array}$ \\
\hline on a wooden plate & rocking & rocking & rocking & sliding only & 0.479 \\
on a iron block & rocking & rocking and sliding & sliding and rocking & sliding only & 0.417 \\
on a graphite block & rocking & rocking and sliding & sliding and rocking & sliding only & 0.372 \\
on a sponge gum plate & rocking & rocking & rocking & rocking and sliding & 0.583 \\
$\sigma$ value & 0.912 & 0.860 & 0.698 & 0.250 & - \\
$3 / 8 \sin 2 \alpha$ & 0.176 & 0.225 & 0.301 & 0.375 & - \\
\hline
\end{tabular}


图-6 Reduction of velocity in the free rocking. $(12 \times 3 \times 3 \mathrm{~cm}$ graphite prism)

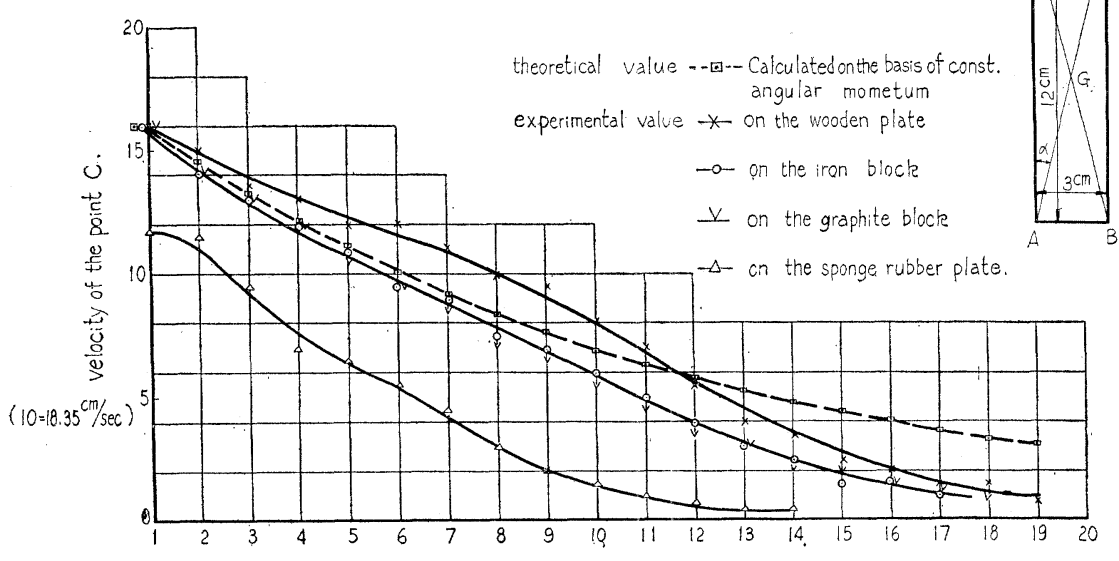

No. of rocking

図-1 Reduction of velocity in the free rocking. $(9 \times 3 \times 3 \mathrm{~cm}$ graphite prism)

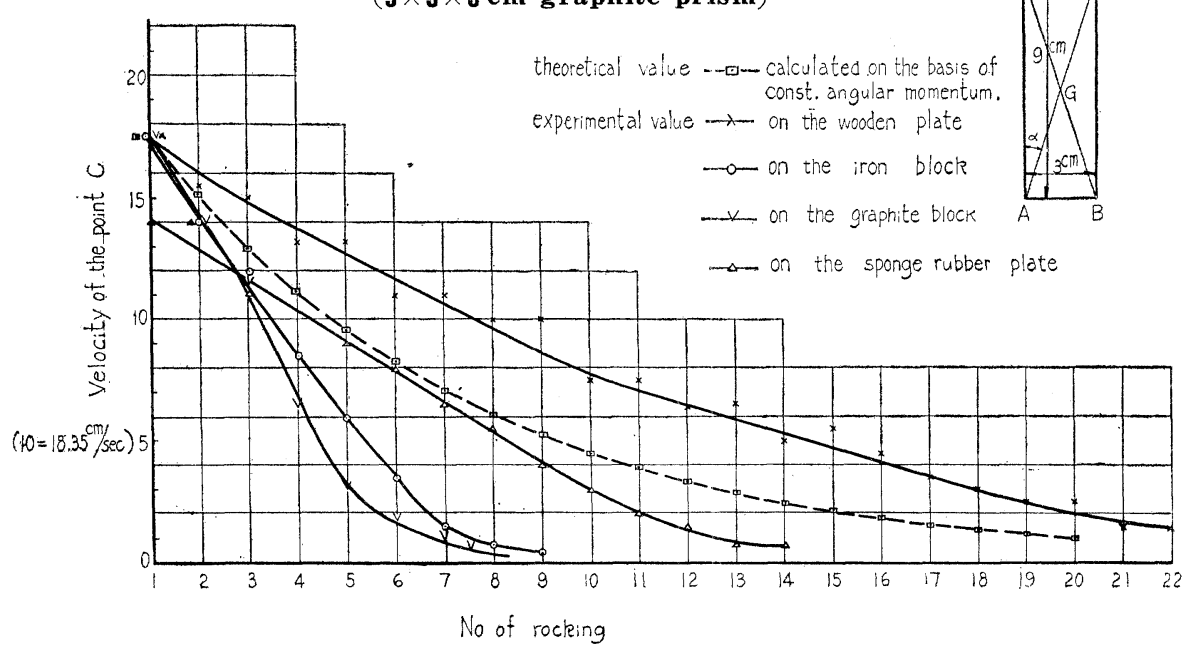

従つて角柱の底面に作用寸る摩擦力との比は次のごとくである。

$$
\frac{\frac{3}{8} \sin 2 \alpha}{\mu}
$$

\section{$\mu:$ 摩擦係数}

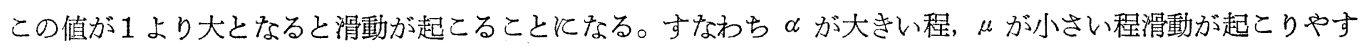

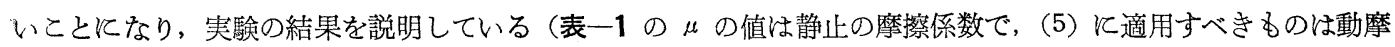
擦的な要素をふくみ, 表の值より相当小さな值を採用すべきものと考光られる)。滑動が起これば角柱のもつエネ ルギーは急激と消費され，ロッキングの減衰が非常に早くなる。低いものでは全くロッキングしないで全部滑動 飞エネルギーが消費される。

次に弾性変形を伴う場合，角柱は基盤仕事をしてエネルギーが消費される。スポンジゴムを基盤飞したとき 高い角柱の減衰の早いのはこのためで，低くなるにつれて減衰が逆に拓とくなるのは，変形による仕事の量より 摩擦の影響の方が大きく現われて滑動を起こさないためと解される。この実験のいずれをとつてるロッキングす る場合の速度減衰の度合は従来の理論飞よつて推定される速度減衰の度合より小であつて，エネルギーの消耗を 伴なわないという前提で一義的と速度減衰の度合を規定する議論と誤があることがわかる。 
図-8 Reduction of velocity in the free rocking.

$(\mathbf{6} \times \mathbf{3} \times \mathbf{3} \mathrm{cm}$ graphite prism $)$

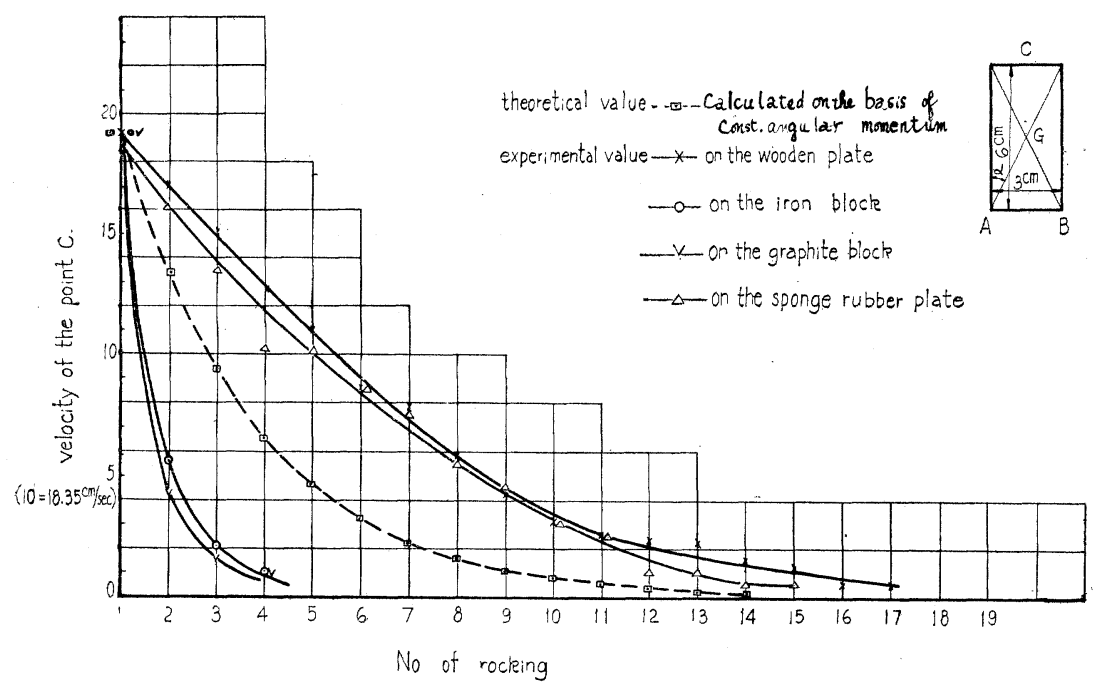

图-9 Reduction of velocity in the free rocking.

$(\mathbf{3} \times \mathbf{3} \times \mathbf{3} \mathbf{c m}$ graphite prism)
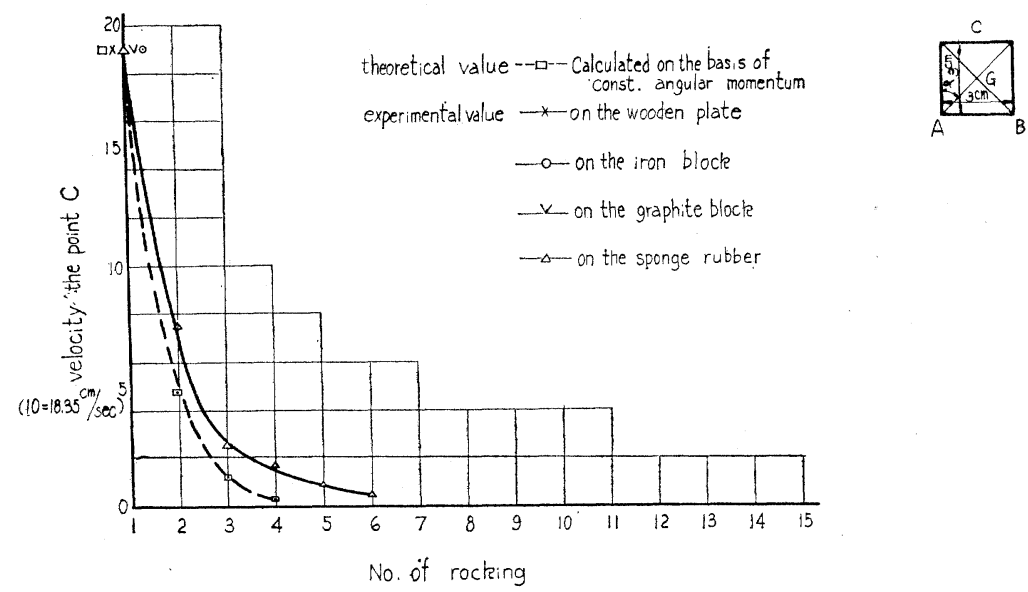

on the iron block

on the graphite blocte

$\rightarrow-$ on the sponge rubber

4. 結論

以上ロッキング現象に路いて一つの吟味を行つた結果, 次のことが明らかになつた。

(1) 従来ロッキングについて求められている運動方程式は実験的にるかなりよく成立するが, 回転端を交換す る際の速度減衰を説明するための角運動量保存則の適用恃訂正されなければならない。

（2）実際のロッキングに括いて速度の娍衰する条件には，口ッキングする物体と基盤との間の摩擦係数，弾性 的性質，扣よびロッキングする物体の形体との他の要素が複雑に関係して来て，従来いわれているような一義的 な規定はできない。

【付記】

本実験の内, 直流増幅器を用いた陰極線オッシログラフによる測定は当研究所, 計測研究室の飯島二郎, 多田 確の両氏を煩わしたもので，両氏に対し厚く謝意を表する次第である。

参考文献

1）烟野 正：振動実験における模型相似律, 土木学会論交集第 61 号, 昭. 34. 3 .

2）木村 集, 飯田洉事：角柱の踊りについて，地震第 6 巻， 3,4 号

3）例之ば坪井忠二：振動論

(昭. 33. 7. 30) 